\title{
Nutritional profile of patients with type 2 Diabetes Mellitus in Ribeirão Preto family health units
}

\author{
Perfil nutricional de pacientes com Diabetes Mellitus tipo 2 em unidades de saúde \\ da família de Ribeirão Preto
}

\author{
Nayara Ragi Baldonia; Amaury Lelis Dal Fabbro \\ a Nutritionist. PhD Student at Ribeirão Preto School of Medicine, University of São Paulo (FMRP-USP). \\ ${ }^{b}$ Medical Doctor. Associate professor, Department of Social Medicine Ribeirão Preto School of Medicine, University of São Paulo (FMRP-USP) \\ Sponsorship Agency: Coordination of Improvement of Higher Education Personnel (CAPES).
}

ABSTRACT $\quad$ Objective: To describe the nutritional profile and the metabolic control of type 2 diabetes mellitus patients in family health units of Ribeirão Preto.

Materials and Methods: This is a descriptive study, inquiry type, with patients registered in family health units of Ribeirão Preto - SP. The sample was 100 patients, being laboratory data assessed by means of medical records. The sociodemographic and clinical variables, as well as those related to the nutritional profile were obtained through home visits. Furthermore, anthropometric evaluation of the patients was performed. Body fat (\%) was assessed by electric bioimpedance. The local Ethics and Research Committee approved this research.

Results: The average age of the patients was 66.7 years, $64 \%$ female, predominantly white (78\%), married (58\%), and with an incomplete basic school level (56\%). The self-reported morbidity with the greatest prevalence was systemic arterial hypertension (71\%). Concerning the nutritional diagnostic, $75 \%$ of the patients were overweight or presented obesity. As regards to glycemic control, it was evidenced that 75 and $60 \%$ of the patients, respectively, were with fasting glycemia and glycated hemoglobin ( $\mathrm{Hb} 1 \mathrm{Ac})$ values above the recommended. The odds ratio was used to verify the association between the biochemical variables and the fat mass. However, no significant association was found. Conclusion: The majority of patients were overweight or had obesity and inadequate metabolic control.

Keywords: nutritional assessment; primary attention; diabetes mellitus.

RESUMO

Objetivo: Descrever o perfil nutricional e o controle metabólico dos pacientes com Diabetes Mellitus, tipo 2 em unidades de saúde da família de Ribeirão Preto.

Materiais e Métodos: Trata-se de um estudo descritivo, tipo inquérito, realizado com pacientes cadastrados em unidades de saúde da família de Ribeirão Preto-SP. A amostra foi constituída por 100 participantes, sendo que os dados laboratoriais foram obtidos por meio de registros em prontuários médicos, e as variáveis sociodemograficas, clínicas, e às relacionadas ao perfil nutricional foram obtidas mediante entrevista domiciliar. Além disso, foi realizada a avaliação antropométrica dos pacientes. Para cálculo da massa de gordura corporal (\%) foi utilizada a bioimpedância elétrica. Os dados foram digitados no software Epi Info ${ }^{T M} 7$ e analisados pelo programa estatístico Stata 9.0. O trabalho foi aprovado pelo Comitê de Ética e Pesquisa.

Resultados: A média de idade dos participantes foi de 66,7 anos, sendo 64\% do sexo feminino, com predomínio de brancos (78\%), casados (58\%), com ensino fundamental incompleto (56\%). A morbidade auto referida de maior prevalência foi a hipertensão arterial sistêmica (71\%). Com relação ao diagnóstico nutricional, observou-se que $75 \%$ dos pacientes estavam com excesso de peso ou obesidade. No que se refere ao controle glicêmico, evidenciou-se que 75 e $60 \%$ dos pacientes, respectivamente, estavam com a glicemia de jejum e hemoglobina glicada (Hb1Ac) acima dos valores recomendados. Utilizou-se o odds ratio para verificar a associação entre as variáveis bioquímicas e a massa de fato. No entanto, nenhuma associação significativa foi encontrada.

Conclusão: A maioria dos pacientes estava com excesso de peso ou obesidade e controle metabólico inadequado.

Palavras-chave: avaliação nutricional; atenção primária; diabetes mellitus. 


\section{INTRODUCTION}

Diabetes mellitus (DM) is a chronic disease that occurs when the pancreas is unable to produce insulin, or when the body can not make good use of the insulin it produces ${ }^{1}$. Type 2 DM is the most prevalent form of DM, which affects 90 to $95 \%$ of cases $^{2}$. The prevalence of DM is increasing worldwide, and currently there are 415 million adults with diabetes and with an estimate of 642 million in 2040. This means that currently one in every eleven adults has a diagnosis of $\mathrm{DM}^{1}$.

The factors that justify this increase in the prevalence of DM are: population growth and aging, urbanization, increasing prevalence of obesity, sedentary lifestyle and increased survival of patients with DM and lifestyle in general $^{3,4}$. The World Health Organization (WHO) shows that the etiological factors related to the increased prevalence of obesity in the world are due to diets with high energy densities associated with a sedentary lifestyle ${ }^{5}$.

Thus, the treatment of diabetes is to modify ones lifestyle and adhere to prescribed treatment regimens ${ }^{6}$. It is valid to point out that non-pharmacological treatment is an effective and essential measure to control DM at any stage of the disease, being able to control glucose levels, prevent complications and slow the onset of drug treatment ${ }^{2}$. This type of treatment includes the following strategies: education, lifestyle modification, increased physical activity, reorganization of eating habits, weight reduction and reduction or abandonment of some vices harmful to health, such as smoking and alcohol ${ }^{7}$.

Adherence to pharmacological and non-pharmacological treatment becomes of great importance as DM is a costly disease, both for the affected individuals and their families, and for the health system, because of its chronic nature, its complications and the means to control the disease ${ }^{8}$. DM is an issue of growing public health so it is necessary to know the nutritional status of patients to implement effective interventions in this area. This study aimed to describe the nutritional profile and metabolic control of patients with DM2.

\section{MATERIALS AND METHODS}

This research is characterized as a descriptive study, inquiry type, conducted with 100 patients from four family health units (FHU) in Ribeirão Preto-SP. Users of both sexes were included, aged over 18 years, registered with and followed by the FHU, diagnosed with DM2, and being registered in the medical records with at least one result of Hb1AC and fasting glycemia over the past 12 months. The electrical bioimpedance equipment was not permitted to be used with patients who undertake dialysis, pregnant women, using pacemakers, receiving chemotherapy, and with dementia, so patients with any of these criteria were excluded from the study.

For identification of patients with DM the information system of primary care (ISPC) was used. Subsequently the medical records of patients, for the verification of blood glucose fasting and $\mathrm{Hb} 1 \mathrm{AC}$, was also used. Invitations to patients to participate in the study were made at home. A pre-test with five patients was performed in order to verify recruitment and research strategy, test instruments collection, check understanding of the respondent, and allow experience for the researcher in the management of these data collection instruments.

Unique and individual anthropometric measurements were performed. The following data were collected: weight $(\mathrm{kg})$, height $(\mathrm{cm})$, waist circumference $(\mathrm{cm})$, hip circumference $(\mathrm{cm})$, thigh circumference $(\mathrm{cm})$ and neck $(\mathrm{cm})$. To obtain the weight of the patients a Plenna ${ }^{\circledR}$ balance with a maximum capacity of $150 \mathrm{~kg}$ and $100 \mathrm{~g}$ division was used. The weigh-in was held with barefoot patients wearing light clothing. Height was measured on an Altura Exata ${ }^{\circledR}$ portable stadiometer for which the respondent remained barefoot, upright, arms hanging with hands flat on the thighs and looking towards the horizon.

With weight and height values, body mass index (BMI) was calculated by the formula $\mathrm{BMI}=$ weight $(\mathrm{kg}) /$ height $^{2}$ $(\mathrm{cm})$, and thus adults were classified according to the WHO (1997) and the elderly according to the criteria of Lipschitz (1994) $)^{9,10}$. Waist circumference (WC) was measured using a flexible inelastic tape. To obtain this data the measurement in centimeters took place on the narrowest part of the trunk, between the iliac crest and the last rib, in centimeters. For WC cutoff the criterion of the National Cholesterol Education Program - NCEP (2001) was used, being represented by the following values: $\geq 102 \mathrm{~cm}$ for men and $\geq 88 \mathrm{~cm}$ for women ${ }^{11}$.

The waist-hip relation (WHR) was calculated as the ratio of waist circumference and hip circumference. For men, risk increased when (WHR >1.0) and for women at increased risk (WHR $>0.85)$. The measurement of neck circumference (NC) was taken at the midpoint of the neck height using a flexible inelastic tape. For classification, the following criteria were used: for men $<37 \mathrm{~cm}$ without risk of being overweight, $\geq 37 \mathrm{~cm}$ at risk of being overweight, and $\geq 39.5 \mathrm{~cm}$ may be associated with BMI greater than $30 \mathrm{~kg} / \mathrm{m}^{2}$; for women, $<34 \mathrm{~cm}$ without risk of being overweight, $\geq 34 \mathrm{~cm}$ with the risk of being overweight and $\geq 36.5 \mathrm{~cm}$ may be associated with $\mathrm{BMI}\left(\mathrm{kg} / \mathrm{m}^{2}\right)$ greater than $30^{12}$.

The assessment of body composition was performed by the bioelectrical impedance method using a BIA- 
Biodynamics ${ }^{\circledR}$, model 450, Body Composition Analyzer, Seatttle, WA, USA. The electrodes were placed on the hands and feet on the right side; one of the electrodes was fixed in the space between the index and middle fingers of the hand and the other on the wrist; on the feet, one of electrodes was positioned between the first and second toe and another in the anterior tibial region. The cutoff points for fat mass percentage were $25 \%$ for men and $35 \%$ for women ${ }^{13}$.

The collected data were entered into Epi Info TM 7 software, which allowed classification of the investigated variables and descriptive analysis of these results. Statistical analyzes were performed using Stata 9.0 software. To perform this evaluation, the $\chi^{2}$ and Fischer's exact tests were used to test associations between groups for categorical variables. To verify differences between continuous quantitative variables, the average test (Student t test) was used. Used the odds ratio to verify the association between the biochemical variables and the fat mass. However, no significant association was found.

The study was approved by the Ethics Committee of the FMRP-USP (CEP-CSE-FMRP-USP), whose approval protocol was No. 857,568.

\section{RESULTS}

A total of 555 patients were identified with DM2 in the ISPC, of which 201 met the inclusion criteria and 100 participants were included in the study (Figure 1). Regarding refusals (17), we observed that most (11) were female with a mean age 65.5 years.

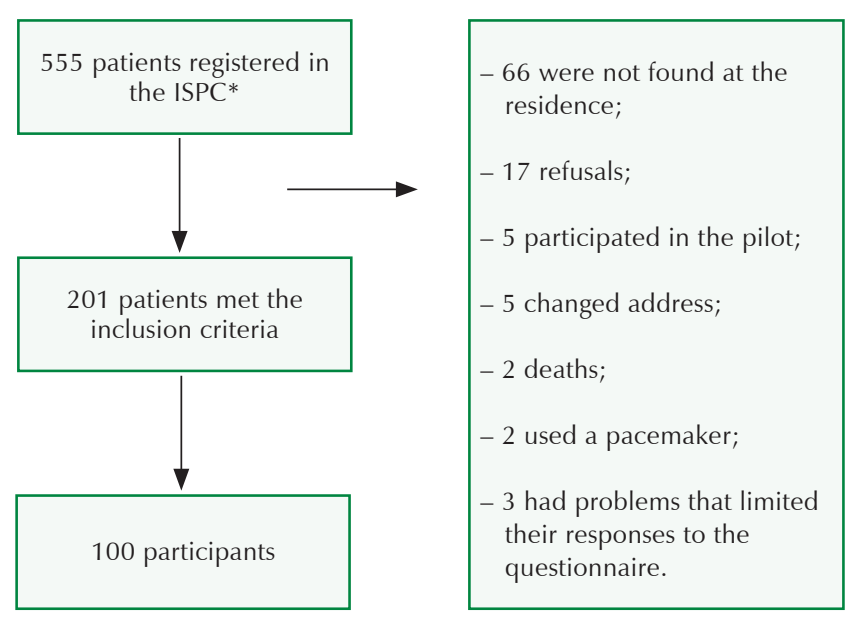

*ISPC: Information System of Primary Care.

Figure 1. Flowchart of identifying patients with type 2 diabetes mellitus $(n=100)$ followed up in the family health units in Ribeirão Preto-SP.
Of the $100(100 \%)$ study participants, the age ranged from 42 to 92 years, with a mean of 66.7 years and a predominance of elderly subjects $(70 \%)$, white $(78 \%)$, female $(64 \%)$, married $(58 \%)$, retired $(63 \%)$ and incomplete primary school education (56\%). Regarding the guidelines received by health professionals, $98 \%$ reported having received guidance on the care with DM2. Professionals most mentioned by the participants were medical (91\%), nurses (21\%) and nutritionists (13\%). Only 4, 2, 1 and $1 \%$, respectively, cited pharmaceutical, physical educator, psychologist and physical therapy as professionals who advise on such care.

Comorbidities associated with DM2 most cited by participants were systemic arterial hypertension (SAH) $(71 \%)$, dyslipidemia (63\%), depression (14\%) and kidney problems (5\%). In addition, $56 \%$ of participants reported having other diseases, the most reported being: "thyroid problem" $(n=9)$, "back problem" $(n=8)$, fibromyalgia $(n=5)$, glaucoma $(n=4)$, cancer $(n=2)$, osteoporosis $(n=4)$ and arthritis $(\mathrm{n}=4)$.

The analysis of nutritional status according to BMI showed that $75 \%$ of adults and elderly individuals were overweight or obese. Among 30 adult patients, most of them were overweight or obese [(overweight $(n=10)$, obesity I ( $n=10)$, obesity II $(n=6)$ and obesity III $(n=2)]$ and only 2 eutrophic adult patients. Regarding nutritional assessment of the elderly, it was observed that most present excess weight $(n=47)$. The others were underweight $(n=2)$ and eutrophic $(n=21)$.

It was observed that women (34.2\%) showed mean values of body fat $(\%)$ higher than men $(25.2 \%)(p<0.05)$ (Table 1). Regarding WC, $41.7 \%$ of men had values that are associated with a risk of cardiovascular disease $(>102 \mathrm{~cm})$, while among women, the prevalence of WC measures above $88 \mathrm{~cm}$ was higher $(75 \%)(p<0.05)$. The WHR presents differences between the sexes with the highest average among men, showing that the majority (63\%) of the total study population is at risk of diseases associated with obesity, being $39 \%$ of men and $77.6 \%$ women.

With the evaluation of $\mathrm{NC}$, it was observed that only $1 \%$ of respondents are at no risk of being overweight, while $34 \%$ are at risk of being overweight and $65 \%$ have NC values associated with BMI greater than $30 \mathrm{~kg} / \mathrm{m}^{2}$.

In relation to metabolic control, $75 \%$ of patients presented higher fasting glycemia above $100 \mathrm{mg} / \mathrm{dL}$ and $60 \%$ had $\mathrm{Hb} 1 \mathrm{Ac} \geq 7$. Of the 75 patients with fasting glycemia $\geq 100 \mathrm{mg} / \mathrm{dL}$, the majority (60\%) presented excess weight gain or obesity (Table 2). There is no association between the biochemical parameters and the percentage of fat mass (Table 3). 
Table 1. Means and standard deviations of anthropometric variables and laboratory characteristics of patients with type 2 diabetes mellitus $(n=100)$ in follow-up in family health units of Ribeirão Preto.

\begin{tabular}{lcccc}
\hline Variables & $\begin{array}{c}\text { Men }(\mathbf{n}=\mathbf{3 6}) \\
\text { Mean }(\mathbf{S D})\end{array}$ & $\begin{array}{c}\text { Women }(\mathbf{n}=\mathbf{6 4}) \\
\text { Mean (SD) }\end{array}$ & $\begin{array}{c}\text { Total }(\mathbf{n}=\mathbf{1 0 0}) \\
\text { Mean (SD) }\end{array}$ & $\boldsymbol{p}^{*}$ \\
Age (years) & $67(11.8)$ & $66.5(10.9)$ & $66.7(11.2)$ & 0.4118 \\
Weight & $83.2(17.2)$ & $71.4(12.1)$ & $75.6(15.2)$ & 0.0001 \\
Height & $167.1(7.8)$ & $153.7(6.5)$ & $158.5(9.5)$ & 0.000 \\
BMI & $29.5(5.3)$ & $30.3(4.8)$ & $30.0(4.9)$ & 0.7657 \\
Fat mass & $25.2(10.5)$ & $34.2(9.8)$ & $31.0(10.9)$ & 0.000 \\
Lean body mass & $74.7(10.7)$ & $65.8(9.8)$ & $69.0(10.9)$ & 0.000 \\
Waist circumfernce & $100.5(9.6)$ & $94.5(9.8)$ & $96.7(10.2)$ & 0.0024 \\
Hip circumference & $101.3(9.7)$ & $106.4(10.2)$ & $104.6(10.3)$ & 0.0085 \\
Thigh circumference & $47.4(5.0)$ & $49.6(5.5)$ & $48.8(5.5)$ & 0.0259 \\
Neck circumference & $42.1(3.1)$ & $37.4(2.6)$ & $39.1(3.6)$ & 0.000 \\
Waist/Hip & $0.98(0.05)$ & $0.88(0.07)$ & $0.92(0.8)$ & 0.000 \\
Neck/Thigh & $0.87(0.13)$ & $0.76(0.08)$ & $0.80(0.1)$ & 0.000 \\
Fasting glycemia & $147.1(55.7)$ & $129.3(48.7)$ & $135.4(51.7)$ & 0.0445 \\
HbA1c (\%) & $8.1(1.7)$ & $7.6(2.0)$ & $7.8(1.9)$ & 0.0837 \\
\hline
\end{tabular}

*Mean comparison test for two independent populations (Student $t$ test). BMI: body mass index; Hb1Ac: glycated hemoglobin.

Table 2. Fasting glycemia ( $\mathrm{mg} / \mathrm{dL})$, according to the nutritional status of patients with type 2 diabetes mellitus $(n=100)$ in follow-up in family health units of Ribeirão Preto.

\begin{tabular}{|c|c|c|c|}
\hline \multirow{2}{*}{ Nutritional State } & \multicolumn{2}{|c|}{ Fasting Glycemia } & \multirow{2}{*}{ Total } \\
\hline & $<100 \mathrm{mg} / \mathrm{dL}$ & $\geq 100 \mathrm{mg} / \mathrm{dL}$ & \\
\hline Malnourished or eutrophic & 10 & 15 & 25 \\
\hline Excessive weight or obesity & 15 & 60 & 75 \\
\hline Total & 25 & 75 & 100 \\
\hline
\end{tabular}

$\chi^{2}=14.0317 ; p=0.051$.

Table 3. Odds ratio of variables laboratory characteristics and percentage of fat mass of patients with type 2 diabetes mellitus $(n=100)$ in follow-up in family health units of Ribeirão Preto.

\begin{tabular}{|c|c|c|c|c|}
\hline & \multicolumn{2}{|c|}{ Hb1Ac } & \multirow{2}{*}{ OR } & \multirow{2}{*}{ IC } \\
\hline & $\geq 7 \%$ & $<7 \%$ & & \\
\hline Percentage of fat mass elevated & 38 & 26 & & \\
\hline \multirow[t]{3}{*}{ Percentage of fat mass adequate } & 22 & 14 & 0,93 & $0,36-2,31$ \\
\hline & \multicolumn{2}{|c|}{ Fasting Glycemia } & P & IC \\
\hline & $<100 \mathrm{mg} / \mathrm{dL}$ & $\geq 100 \mathrm{mg} / \mathrm{dL}$ & 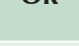 & $\pi$ \\
\hline Percentage of fat mass elevated & 45 & 19 & & \\
\hline Percentage of fat mass adequate & 30 & 6 & 0,47 & $0,13-1,43$ \\
\hline
\end{tabular}

Hb1Ac: glycated hemoglobin; OR: odds ratio: IC: confidence interval.

\section{DISCUSSION}

The high frequency of elderly in this study can be justified by the clinical profile of DM2 which affects older individuals, because with increasing age there is progressive pancreatic beta-cell dysfunction ${ }^{14}$. Similar frequencies were found in other epidemiological studies on patients with DM2 $2^{15,16}$. Because the majority of respondents are married, it is believed that eating habits are determined by a supposed routine, hindering the action of health professionals on the changes necessary to implement a food plan ${ }^{17}$. 
It was observed that most did not finish primary school education (56\%), a result similar to the study of Jost and colleagues (2010), held in the city of Luzerna in the Brazilian state of Santa Catarina, which found $67 \%$ of patients with DM2 with incomplete elementary school ${ }^{18}$. According to Silva (2010), low education deserves attention when the achievement of good metabolic control of DM2 is required, as this factor can influence the understanding of the guidelines offered by health professionals, including the correct use of medicines and nutritional follow-up ${ }^{19}$. Data from VIGITEL (2014) show that in both sexes the frequency of DM decreased strongly with the highest level of education of respondents ${ }^{20}$.

Even with the reduced proportion of patients who reported receiving guidance from a nutritionist $(13 \%)$, it is valid to point out that Article 6 of Law No. 8080 of 1990 "provides nutritional counseling" to patients assisted by the public health system (PHS) ${ }^{21}$. The lack of such guidance can be justified by the lack of this professional in the four study units. Also noteworthy is that in a study conducted in Ribeirão Preto-SP of patients with DM, it was observed that most nutritional guidelines (96.5\%) were performed by physicians ${ }^{22}$.

In this context, it is important to emphasize the relevance of nutritional counseling in the treatment of patients with DM conducted by a nutritionist, because scientific evidence shows that nutritional monitoring favors glycemic control, causes a reduction in Hb1Ac levels, regardless of the type of DM and time diagnosis, and with this reduces costs to the health system ${ }^{23-25}$

Regarding the comorbidities associated with DM2, a study in southern Brazil with DM2 patients in a unit of primary health care, found a smaller proportion $(27.1 \%)$ of patients who had DM and SAH concomitantly ${ }^{26}$. Currently $\mathrm{SAH}$ and DM2 are among the top five global risks for overall mortality ${ }^{27}$. Because these comorbidities can be avoided and controlled through healthy lifestyle habits, it is very important that health staff work in implementing actions that promote physical and healthy eating activities, in order to prevent micro and macrovascular complications related to $\mathrm{DM} 2^{28}$

With regard to the nutritional status of the participants it is important to consider that being overweight and obesity are risk factors for the development of insulin resistance, which is the main feature of $\mathrm{DM} 2^{29}$. This finding reinforces the need for prevention actions and control of DM2 in an interdisciplinary way, including professional nutritionists and fitness trainers as effective and permanent members of health teams. The nosological data related to the anthropometric profile of Brazilians also reinforces this need for interventions to improve lifestyle, as Brazil is among the countries with the highest prevalence of overweight people ${ }^{20}$.

Studies show the positive association of increased fat mass (\%) with the development DM2 ${ }^{30,31}$. The fact that women present average fat mass (\%) higher than men is in agreement with the literature, showing that women have a higher percentage of fat mass ${ }^{13}$. This is because for men about $3 \%$ body fat is considered essential while in women the essential fat is higher (12\%). This statement is justified by the higher percentage of body fat in the breasts, pelvic region and thighs ${ }^{31}$.

This is a result that resembles another study in which there was a higher prevalence of abdominal obesity among women $^{32}$. WC is a common measure in nutritional evaluation studies in patients with DM2 that is used to assess abdominal fatness according to their association with non-communicable chronic diseases (NCD) $)^{33-36}$. Recent studies have found a positive association between abdominal obesity and $\mathrm{DM} 2^{37,31}$. One reason for this high prevalence of individuals with increased WC in this study is that the majority (61\%) of those here investigated have a sedentary lifestyle.

Regarding metabolic control, the results of this study corroborate the study by Sampaio \& Figueiredo ${ }^{38}$, in which the majority of respondents have high levels of both markers (fasting glycemia and $\mathrm{Hb} 1 \mathrm{Ac}$ ). These results show that the disease is not adequately controlled. In this regard, such patients require continued support from the perspective of education in DM, to achieve the targets set to control the disease.

However, it must be considered that when planning education in DM for this population, it is important that the health team takes into account the level of education and age of individuals, since $56 \%$ of them have only completed elementary school, and $70 \%$ are elderly. These characteristics require specific strategies to promote self-care and empowerment of patients.

It was observed that there was no association between the biochemical parameters and the percentual of fat mass. However, data from the literature show the relationship between fat deposition, mainly in the abdominal region, and the increase in insulin resistance ${ }^{39}$. A cohort study performed with patients with Diabetes Mellitus showed that nutritional therapy contributed to the better adaptation of the anthropometric and biochemical variables ${ }^{40}$.

The present study shows that the vast majority of patients with DM2 are overweight and/or obese, and most have poor metabolic control. Faced with such evidence, there is a need to implement nutritional strategies to improve nutritional care and consequently provide better glycemic control of patients with DM2. 


\section{ACKNOWLEDGMENT}

I thank the patients with Diabetes Mellitus, who accepted to participate in this study, enabling the transformation of a project into scientific evidence.

\section{REFERENCES}

1. Internacional Diabetes Federation (IDF) [Internet]. [capturado 15 de abril 2016]. Disponível em: http://www.diabetesatlas.org

2. American Diabetes Association (ADA). Classification and Diagnosis of Diabetes. Diabetes Care. 2016;39(1):3-23.

3. Hu FB. Globalization of diabetes: The role of diet, lifestyle and genes. Diabetes Care. 2011;34(6):1249-57. https://doi.org/10.2337/dc110442

4. Kaur JA. Comprehensive review on metabolic syndrome. Cardiol Res Pract. 2014;2014:943162. https://doi.org/10.1155/2014/ 943162

5. World Health Organization (WHO). 10 facts on obesity [Internet]. [capturado 08 de janeiro de 2016]. Disponível em: http://www. who.int/features/factfiles/obesity/facts/en/index4.html

6. Brazilian Society of Diabetes. Epidemiology and prevention of diabetes mellitus. Rio de Janeiro: National Editorial Group; 2015.

7. Chatterjee S, Davies MJ. Current management of diabetes mellitus and future directions in care. Postgrad Med J. 2015;91(1081): 612-21. https://doi.org/10.1136/postgradmedj-2014-133200

8. Grant P. How much does a diabetes out-patient appointment actually cost? An argument for PLICS. J Health Organ Manag. 2015;29(2):154-69. https://doi.org/10.1108/JHOM-01-2012-0005

9. World Health Organization (WHO). Obesity: preventing and managing the global epidemic. Report of a OMS consultation on obesity, 3-5 June, 1997. Geneva: WHO; 1997.

10. Lipschitz DA. Screening for nutritional status in elderly. Prim Care. 1994;21(1):55-67.

11. National Cholesterol Education Program (NCEP). Executive Summary of the Third Reporto of the National Cholesterol Education Program (NCEP). Expert panel on detection, evalution, treatment of high blood cholesterol in adults (Adult Treatment panel III). JAMA. 2001;285(19):2486-97. https://doi.org/10.1001/jama.285. 19.2486

12. Vitolo MR. Adult nutritional assessment. Rio de Janeiro: Rubio; 2008.

13. World Health Organization. Obesity. Preventing and managing the global epidemic Report of a WHO Consultation. Geneva: WHO; 2000. (WHO technical report series; 894).

14. Tata V. Age-related impairment of pancreatic beta-cell function: pathophysiological and cellular mechanisms. Front Endocrinol (Lausanne). 2014;5:138.

15. Barbieri AFS, Chagas IA, Santos MA, Teixeira CRS, Zanetti, ML. Food intake of type 2 Diabetes Mellitus patients. Rev Enferm. 2012;20(2):155-60.

16. Oliveira KCS, Zanetti ML. Knowledge and attitudes of patients with diabetes mellitus in a primary health care system. Rev Esc Enferm USP. 2011;45(4):862-8. https://doi.org/10.1590/S008062342011000400010
17. Beverly EA, Miller CK, Wray, LA. Spousal support and food-related behavior change in middle-aged and older adults living with type 2 diabetes. Health Educ Behav. 2008;35(5):707-20. https:/doi. org/10.1177/1090198107299787

18. Jost BS, Hilgemberg E, Rodrigues EB, Daniotti AF, Bonamigo EL. Prevalence of diabetic retinopathy in patients affected by type 2 diabetes mellitus in the city of Luzerna-SC. Arq Bras Oftalmol. 2010;73(3):259-65. https://doi.org/10.1590/S0004-2749 2010000300010

19. Silva LMC, Palha PF, Barbosa GR, Protti ST, Ramos Ada S. Pensioners with type 2 diabetes in the Family Health Program in Ribeirão Preto, São Paulo - Brazil. Rev Esc Enferm USP. 2010;44(2):457-63.

20. Vigitel: Sistema de Vigilância de Fatores de Risco e Proteção para doenças crônicas por inquérito telefônico [Internet]. 2014 [capturado 28 de outubro de 2015]. Disponível em: http://portalsaude.saude. gov.br/images/pdf/2015/abril/15/PPT-Vigitel-2014

21. Brazil (1988 Constitution). It regulates the conditions for promoting the protection and recovery of health, organization and functioning of the corresponding services and gives other providences. Official Gazette [Internet]. 1990 [capturado 08 de janeiro de 2016]. Disponível em: http://www.planalto.gov.br/ccivil 03/leis/L8080.htm

22. Guimarães FPM, Takayanagui AMM. Advices received from health service by patients for the treatment of type 2 diabetes mellitus. Rev Nutr. 2002;15(1):37-44. https://doi.org/10.1590/S1415-5273 2002000100005

23. Liu H, Zhang M, Wu X, Wang C, Li Z. Effectiveness of a public dietitian-led diabetes nutrition intervention on glycemic control in a community setting in China. Asia Pac J Clin Nutr. 2015;24(3):525-32.

24. Obreli-Neto PR, Marusic S, Guidoni CM, Baldoni Ade O, Renovato RD, Pilger D, Cuman RK, Pereira LR. Economic evaluation of a pharmaceutical care program for elderly diabetic and hypertensive patients in primary health care: a 36-month randomized controlled clinical trial. J Manag Care Spec Pharm. 2015;21(1):66-75. https:// doi.org/10.18553/jmcp.2015.21.1.66

25. Webb MC, Aguilal JJ. Nutritional Knowledge, Attitude and Practice among Patients with Type 2 Diabetes in North Central Health Authority in Trinidad and Tobago. West Indian Med J. 2015;65(1):170-6.

26. Lima LA, Nedel FB, Olinto MTA, Baldisserotto J. Hábitos alimentares de hipertensos e diabéticos atendidos em um serviço de Atenção Primária à Saúde do Sul do Brasil. Rev Nutr. 2015;28(2):197-06. https://doi.org/10.1590/1415-52732015000200008

27. Ozcariz SG, Bernardo CO, Cembranel F, Peres MA, GonzálesChico DA. Dietary practices among individuals with diabetes and hypertension are similar to those of healthy people: a populationbased study. BMC Public Health. 2015;15:479-89. https://doi. org/10.1186/s12889-015-1801-7

28. American Diabetes Association (ADA). Microvascular Complications and Foot Care. Diabetes Care. 2016;39(1):72-81.

29. Defronzo RA, Tripathy D. Skeletal muscle insulin resistence is the primary defect in type 2 diabetes. Diabetes Care. 2009;32 Suppl 2:S157-63. https://doi.org/10.2337/dc09-S302

30. Kim CH, Kim HK, Kim EH, Bae SJ, Park JK. Association between changes in body composition and risk of developing Type 2 diabetes in Koreans. Diabet Med. 2014;31(11):1393-8. https://doi. org/10.1111/dme.12527 
31. Tao R, Du H, Zhou J, Su J, Yang J, Hu Y, Ma L, Zhou R, Bean Z, Guo, Y, Chin Z, Li L, Wu M. Relationship between anthropometric measures and the prevalence of diabetes in adults of Suzhou city, Jiangsu province. Chin J Epidemiol. 2014;35(12):1337-42.

32. Gee M, Mahan MLK, Escott-Stump S. Weight control. In: Mahan LK, Stump. Krause SE. Food, nutrition \& diet therapy. 12th ed. Rio de Janeiro: Elsevier; 2010. p. 532-62.

33. Mc Donald A, Bradshaw RA, Fontes F, Mendoza EA, Motta JÁ, Cumbrera A, Cruz C. Prevalence of obesity in panama: some risk factors and associated diseases. BMC Public Health. 2015;15:107587. https://doi.org/10.1186/s12889-015-2397-7

34. Lecube A, Ciudin A, Sampol G, Calladares S, Hernandez C, Simó R. Effect of glycemic control on nocturnal arterial oxygen saturation: a case-control study in type 2 diabetic patients. J Diabetes. 2015;7(1):133-8 https://doi.org/10.1111/1753-0407.12197

35. Silaghi CA, Silaghi H, Craciun AE, Farcos A, Calosi HÁ, Cosma DT, Pais R, Hâncu N, Geogescu CE. Age, abdominal obesity, and glycated hemoglobin are associated with carotid atherosclerosis in type 2 diabetes patients with nonalcoholic fatty liver disease. Med Ultrason 2015;17(3):300-7. https://doi.org/10.11152/mu.2013. 2066.173.cas
36. Mogre V, Apala P, Nsoh JA, Wanaba P. Adiposity, hypertension and weight management behaviours in Ghanaian type 2 diabetes mellitus patients aged 20-70 years. Diabetes Metab Syndr. 2016;10(1 Suppl 1):S79-85. https://doi.org/10.1016/j.dsx.2015.09.022

37. Khan A, Faheem M, Shah ST, Hadi A, Rafiullah, Ahmad S, Gul AM, Shah SF, Jan H, Hafizullah M. Frequency of abdominal obesity and its association with diabetes mellitus among people of peshawar. J Ayub Med Coll Abbottabad. 2015;27(3):617-9.

38. Sampaio LR, Figueiredo VC. Correlation between body mass index and body fat distribution anthropometric indices in adults and the elderly. Rev Nutr. 2005;18(1):53-61. https://doi.org/10.1590/ S1415-52732005000100005

39. Pereira LO, Francischi RP, Lancha Jr AH. Obesidade: hábitos nutricionais, sedentarismo e resistência à insulina. Arq Bras Endocrinol Metab. 2003;47(2):111-27. https://doi.org/10.1590/ S0004-27302003000200003

40. Geraldo JM, Alfenas RCG, Alves RDM, Salles VFS, Queiroz $\mathrm{VMV}$, Bitencourt MCB. Intervenção nutricional sobre medidas antropométricas e glicemia de jejum de pacientes diabéticos. Rev Nutr. 2008;21(3):329-40. https://doi.org/10.1590/S141552732008000300008 